\title{
Stability Product Form Terminology
}

National Cancer Institute

\section{Source}

National Cancer Institute. Stability Product Form Terminology. NCI Thesaurus. Code C96074.

Terminology developed to support Product Forms within the Stability Data Standards. 